\title{
Development of literacy-based learning for Pancasila and citizenship education in senior high school
}

\author{
Nuryati, Ahmad Nasir Ari Bowo*, Paiman \\ Cokroaminoto University, Jl. Perintis Kemerdekaan, Yogyakarta, Indonesia \\ *Corresponding e-mail: ahmadnasir@ucy.ac.id
}

\begin{abstract}
Pancasila is the five principles which becomes the Indonesian ideology. The literacy culture of students, especially in Pancasila and citizenship education learning, is still low. The results of a preliminary observation we did at several high schools in Bantul Regency, Yogyakarta, showed that the problem of Pancasila and citizenship education learning was the students' low literacy skills. Solutions are needed to overcome these problems. An alternative solution about literacy based on Pancasila and citizenship education learning model is needed. The citizenship education learning process based on literacy can improve the literacy skills of students. The purpose of this study is to produce a literacy-based Pancasila and citizenship education learning model in senior high school. This type of research is qualitative. The location of this research is senior high schools in Bantul, Yogyakarta. The results showed that the literacy based on Pancasila and citizenship education learning model in senior high schools were: first, school support about literacy culture. Literacy culture facilities include education and school policies and school facilities. Second, the development of literacy based on Pancasila and citizenship education learning include: (1) preliminary stages include: orientation, apperception, motivation, and giving ignorance. Literacy developed is cultural literacy. (2) The core stages include stimulation, problem statements, data collection, verification, and concluding. The literacy developed is cultural literacy, literacy, digital literacy, and scientific literacy. (3) The concluding stage includes summarizing conclusions, reinforcement, feedback, and closing greetings. Literacy activities developed are cultural literacy and reading-writing literacy.
\end{abstract}

Keywords: learning model, literacy, Pancasila and citizenship education

How to cite: Nuryati, Bowo, A. N. A., \& Paiman. (2021). Development of literacy-based learning for Pancasila and citizenship education in senior high school. International Journal on Education Insight, 2(1), 1-10. DOI: http://dx.doi.org/ijei.v2i1.3003

\section{INTRODUCTION}

The results of preliminary observations in several senior high schools and equals in Bantul Regency, Yogyakarta show that the literacy culture of students is still low. This can be seen from the activities of students both during the learning process and outside learning at school. Students' low literacy culture during the learning process of Pancasila and citizenship education, among others: low interest in reading books, lack of enthusiasm of students during the discussion, students are not interested in learning. Meanwhile, the low literacy culture of students outside of learning, among others lack student interest in accessing information or the latest news on government or state conditions, not many students visit the library, etc.

The generally low level of student literacy culture also applies in various regions, that is, he literacy skills of students are still low (Saadati \& Sadli, 2019). The reading interest and literacy of the Indonesian people are issues that must be taken seriously (GLN, 2017). The low literacy culture of students has an 
impact on learning objectives, especially in Pancasila and citizenship education subjects. It can be seen that, until now, the goals of Pancasila and citizenship education have not been achieved properly. This can be seen from the various problems that exist, including tax awareness issues, corruption problems, environmental problems, moral decadence problems, national disintegration problems, law enforcement problems (Paristiyanti, 2016). Obstacles experienced by Pancasila and Citizenship Education in the learning process so far, namely always emphasizing cognitive aspects, lack of teacher competence, and monotonous teacher learning methods (Widiatmaka, 2016). Students are easily bored in the learning process (Nuryati, Budiutomo, \& Bowo, 2017). One of the factors causing this problem is low literacy culture.

Fostering a literacy culture for students is very important to realize the goals of Pancasila and citizenship education. Literacy is the ability to identify, understand, interpret, create, communicate, calculate, utilize technology, and write material in different contexts (Grant, 1986). Literacy involves a continuous learning process, developing knowledge and potential, and being able to participate in society to achieve expected goals (Grant, 1986). Literacy is important in nation-building because functionally literacy is the basis of all forms of success both in school and in life. In the global market, literacy is highly demanded so that people can actively participate in wider community and international activities such as international conferences, research exchanges, joint research, and business and trade. Being literate not only contributes to personal development or personal learning but being literate also leads to success in school and life (Rintaningrum, 2009). The dimensions of literacy include literacy, numeracy literacy, scientific literacy, digital literacy, financial literacy, and cultural and civic literacy (GLN, 2017). Thus, the students' literacy skills are very important in realizing the goals of Pancasila and citizenship education in particular.

The purpose of citizenship education is to produce citizens who are information literate, citizens who are committed and play an active role in the life of the nation and state, citizens who are autonomous and critical and moral (Pike, 2006). The same thing was conveyed by David et al. (2008). The purpose of citizenship education, especially in Indonesia, is to have a sense of nationality and love for the country in the context of Pancasila values and morals, the values and norms of the 1945 Constitution of the Republic of Indonesia, the values and commitment of Bhinneka Tunggal Ika, as well as a commitment to the integrity of the Unitary State, Republic of Indonesia. (Winataputra, 2016). Pancasila and Citizenship Education aims to develop the potential of students in all dimensions of citizenship, such as (1) The attitude of citizenship includes the constancy, commitment and responsibility of citizenship, (2) Citizenship knowledge, and (3) Citizenship skills including the ability and participation of citizens (Nuryadi \& Tolib, 2017). Pancasila and citizenship education aims to make students know the identity of the nation and have a commitment to build the country following the existing constitution.

An alternative solution to overcome this problem is the need for the implementation of the development of literacy based on Pancasila and civic education learning so that a literacy based on Pancasila and citizenship education learning model is obtained. Teachers must be able to develop and collaborate with various innovative learning models (Bowo, 2016). Teachers must also be able to develop online learning (digital literacy) (Lestari et al., 2020). The development of literacy based on Pancasila and civic education learning can train independence, creativity, innovation, and students to learn

IJEI, Vol. 2, No. 1, April 2021, 1-10 
more effectively and can develop in the areas of competence, character, and student literacy (Leksono, 2019). Citizenship education teachers have a strategic role in shaping and developing literacy in students as young citizens (Benaziria, 2018). Thus, the literacy based on learning model for Pancasila and citizenship can realize the literacy skills of students and the goals of Pancasila and citizenship education.

The purpose of this study is to find literacy based on learning models for Pancasila and citizenship education, especially at the senior high school level. The questions in this study are (1) how is the implementation of literacy culture in SMA equivalent in the Bantul district? (2) how is the development of Pancasila and civic education learning in senior high schools and equals in Bantul district? (3) how is the Learning Model of Pancasila and Citizenship Based on Literacy in Senior High Schools and Equals in Bantul district? Through these three research questions, was found that the ideal Pancasila and citizenship based on literacy education model for the high school level is capable of fostering the culture and literacy abilities of students, and the learning objectives of Pancasila and citizenship education are achieved. This research is the development of pre-existing research related to the topic under study. The novelty of this study is a literacy based on learning model for Pancasila and citizenship education at the high school level.

\section{RESEARCH METHOD}

This research is a qualitative case study type. The place of this research is several senior high schools and equals in Bantul Regency, including Senior High School 1, Vocational High School 1, Health Vocational High School, and Muhammadiyah High School. The stages in this research, among others (1) Researchers conduct pre-research by looking at the problems that exist in general field. Next, formulate problems and research proposals and permits. (2) Field Research. Researchers dig, collect data through observation, interviews, and study documentation. (3) Researchers conducted data analysis. (4) The researcher analyzed the documentation and continued to make a research report.

Data collection techniques and instruments in this study include (1) interview, by asking some unstructured questions about the implementation of the development of literacy based on Pancasila and citizenship learning in high schools and equals. The interviewees included the principal or vice-principal of the curriculum section, Pancasila and citizenship education teachers, and students. (2) Documentation, the documentation instrument needed in this study is a learning implementation plan of Pancasila and citizenship education. (3) Observation, the researcher goes down to the field to observe things related to the required data. The data collection procedure of this research used 2 kinds of triangulation, namely the triangulation of techniques and triangulation of data sources. Data analysis techniques in this study include (1) data collection, carried out in the research location through interviews, observation, and documentation study. (2) Data reduction, the researcher selects and selects the data that has been obtained. (3) Presenting data, the researcher presents the data in the form of descriptions, as well as images or matrices to make it easier to understand the research being studied. (4) Withdrawing conclusions, after presenting the data, the final part is to make a research conclusion. 


\section{RESULTS AND DISCUSSION}

Learning is a process by which a teacher transfers knowledge to students. So that, when learning is complete, students can acquire new knowledge and can be applied in their lives (Bowo, 2015). The learning model is a step or procedure in the implementation of learning (Nuryati \& Budiutomo, 2017). Citizenship Education aims to make the Indonesian people have awareness as citizens (Bowo, 2016). Today's literacy is more complex, not only understanding text, language, and language skills, but more than that. Today's literacy includes all activities or daily activities (Bomer et al., 2019). Literacy based on Pancasila dan citizenship education learning contains literacy components. Literacy components today are not just reading and writing, but related to all one's activities in daily life. It is necessary to develop citizenship education learning so that the objectives of citizenship education learning can be implemented properly. In the description below, the details research from development of Pancasila and citizenship education learning based on literacy are presented.

\section{Literacy culture at senior high schools in Bantul regency}

The results of interviews, observations, and documentation studies at Senior High Schools 1 Sewon, Vocational High School 1, Health Vocational High School, and Muhammadiyah Senior High School, Bantul regency, in more detail, the literacy culture in Senior High School and Equals in Bantul Regency is as shown in Figure 1.

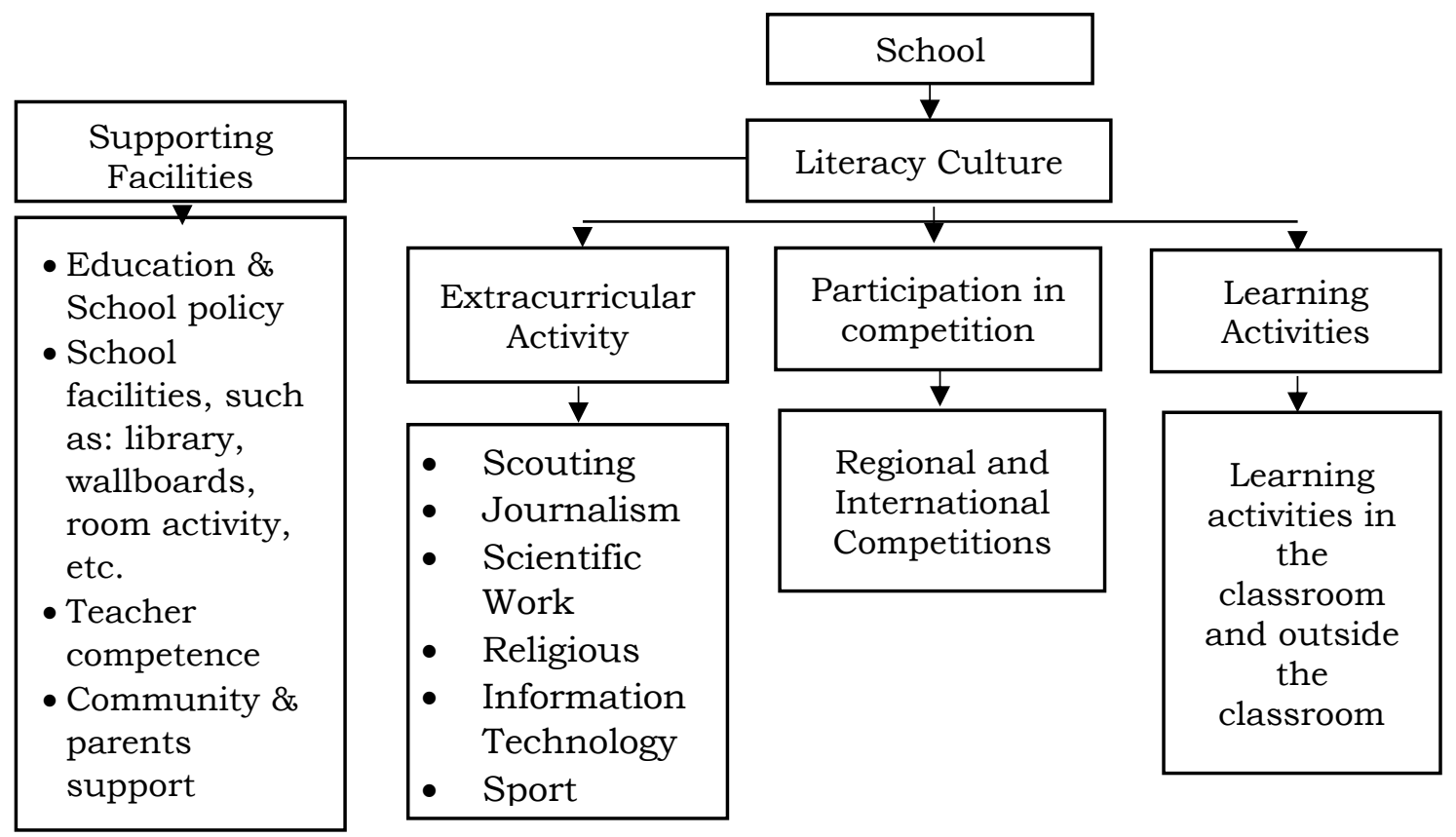

Figure 1. Literacy culture in senior high schools in Bantul regency

It can be seen that the literacy culture in these schools includes: extracurricular activities, participation in national and regional competitions, learning activities in class, and outside the classroom. These extracurricular activities include religious activities, scientific work, sports, computers, scouting, and other extracurricular activities. The supporting facilities for this activity include government and school policies, as well as school facilities including practice laboratories, libraries, wallboards, sports rooms and sports 
facilities, and other supporting facilities. Besides, there is also support from the community and parents, as well as professional human resources, both teachers and other school employees.

The results of the research above are by what was conveyed by several experts literacy culture is very important for students to prepare for independent life after graduating from school and also in relationships both in the community and community (Merga et al., 2020). Literacy activities in the form of attitudes, behavior, habits of students in activities at school (Mangeya, 2019). Literacy culture can be implemented through the example of teachers and school principals, the availability of school work programs, literacy development through collaboration with school members, reading habits, and other activities (Marmoah \& Hartono, 2019). Literacy culture in schools can be seen through the activities of students in various activities. Among them are learning activities, extracurricular activities, and other activities that have been prepared through the school work program.

\section{Pancasila and citizenship education learning based on literacy at senior high schools in Bantul regency}

The implementation of Pancasila and citizenship education learning based on literacy consists of several activities, are: (1) Learning activities generally include preliminary, core, and closing activities. preliminary activities include orientation, perception, motivation, and offering indifference. The literacy developed is cultural literacy. The core activities include stimulation, problem statement, data collection, levers, and pulling. The literacy developed is cultural literacy, literacy, digital literacy, and scientific literacy. Finally, the closing activities include reports, reinforcement, and feedback as well as closing greetings. The literacy developed is cultural literacy and literacy. (2) generally, Literacy that is often applied is the content of cultural literacy, scientific literacy, digital literacy, and literacy in every learning process. As for the media and learning tools used to support literacy, among others: LCD, computer, picture, internet, handphone/gadget, and other props. The learning resources used include textbooks, modules, magazines, newspapers, internet sites, digital platforms, society, and the environment.

One of the developments is in Pancasila and Citizenship Education subject. The results of the discussion related to Pancasila and citizenship education learning based on literacy in several Senior High Schools and Equals to Bantul Regency, Yogyakarta can be seen in Figure 2. 


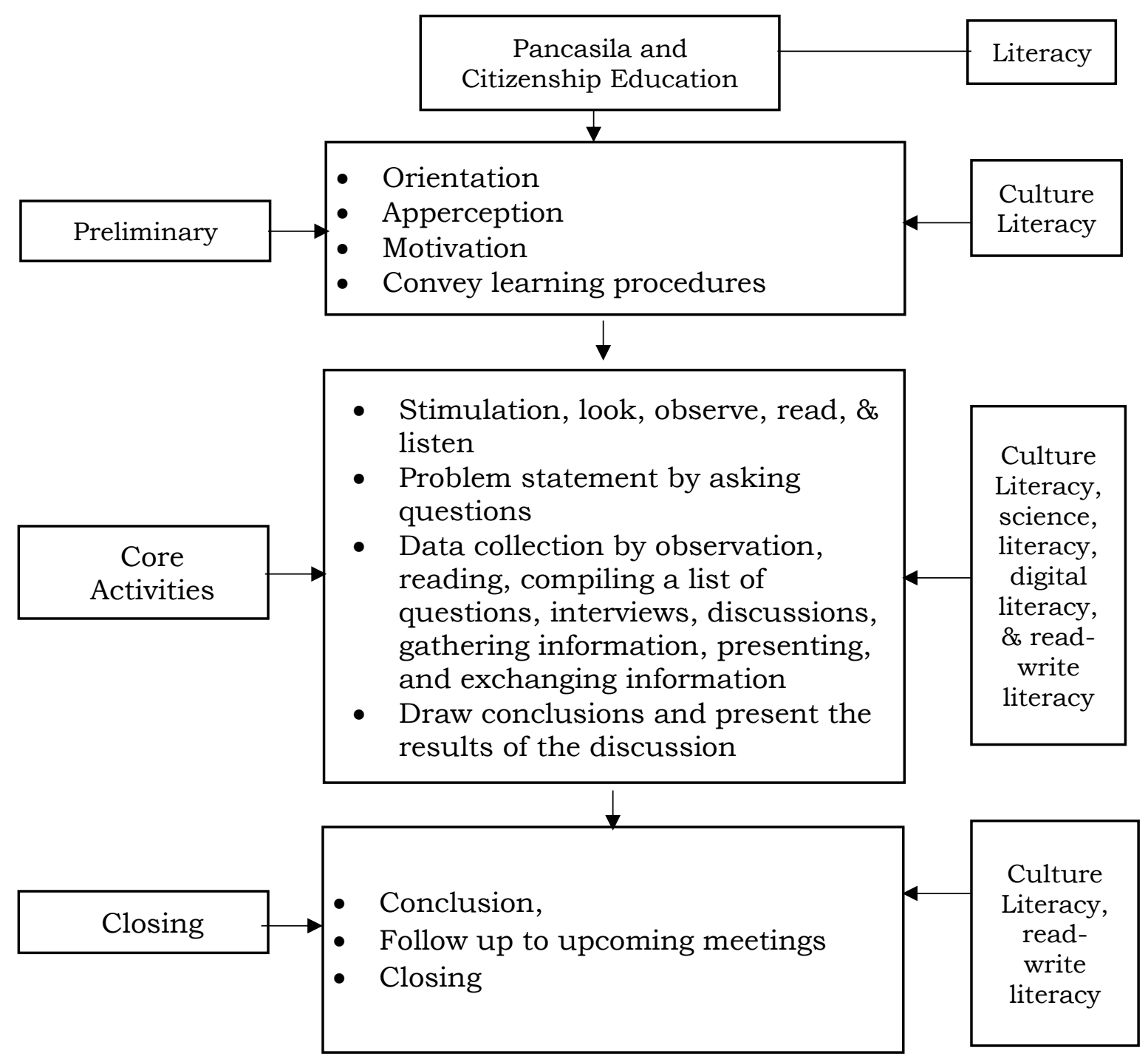

Figure 2. Pancasila and citizenship education learning based on literacy in senior high schools

\section{Pancasila and citizenship education learning based on literacy model at senior high schools in Bantul regency}

Literacy culture in schools can be carried out by various activities at school, including extracurricular activities, learning activities, and other activities. This is by the theory which states that literacy activities are in the form of attitudes, behavior, habits of students in activities at school (Mangeya, 2019). Literacy culture can be implemented through the example of teachers and school principals, the availability of school work programs, literacy development through collaboration with school members, reading habits, and other activities (Marmoah \& Hartono, 2019). Furthermore, literacy-based learning, especially in Civics subjects, is now more complex, not only related to reading and writing. This is according to the theory put forward by Bomer et al. (2019) argues that today's literacy is more complex, not only understanding text, language, and language skills, but more than that, today's literacy includes all daily activities or activities. 
The implementation of literacy culture in Senior High Schools in Bantul Regency, Yogyakarta includes: (1) extracurricular activities include scouting, journalism, religion, sports, and information technology. (2) Participation of students in competitions both regional and national. (3) Learning activities both in class and outside the classroom. Furthermore, supporting facilities for literary culture in schools include education and school policies, school facilities including libraries, wallboards, extracurricular activity spaces, teacher competence, and community/parent support.

The development of Pancasila and citizenship education learning based on literacy at Senior High School and Equals in Bantul Regency generally includes the stages of preliminary activities, core activities, and closing activities. Literacy is often used in every stage of learning includes cultural literacy, digital literacy, scientific literacy, and literacy. Pancasila and citizenship education learning media tools used to support literacy, among others: LCD, computer, picture, internet, handphone/gadget, video, dan media, or other props. Learning resources used include textbooks, modules, magazines, newspapers, internet sites, digital platforms, society, and the environment.

Pancasila and citizenship education learning model based on literacy at Senior High School and Equals in Bantul Regency includes several stages, namely (1) school support about literacy culture. Literacy culture facilities include education and school policies, school facilities including libraries, school boards, extracurricular activity spaces, community support, and parents. (2) Literacy culture in schools in the form of extracurricular activities, learning activities both in class and outside the classroom, participation in preparation and implementation of competitions both regional and national. (3) the development of Pancasila and Citizenship Education based on literacy learning, among others (a) the preliminary activity stages include orientation, perception, motivation, and giving ignorance. The literacy developed is cultural literacy. (b) Core activities include stimulation, problem statement, data collection, verification, and concluding. The literacy developed is cultural literacy, literacy, digital literacy, and scientific literacy. (c) Finally, the closing activities include summarizing conclusions, reinforcement and feedback, and closing greetings. Literacy activities developed are cultural literacy and literacy. Recommendations for the next research are necessary to develop Pancasila and citizenship education based on literacy modules or teaching materials.

The results of the discussion related to the development model of Pancasila and citizenship education learning based on literacy at Senior High Schools in Bantul Regency, Yogyakarta can be seen in Figure 3. 


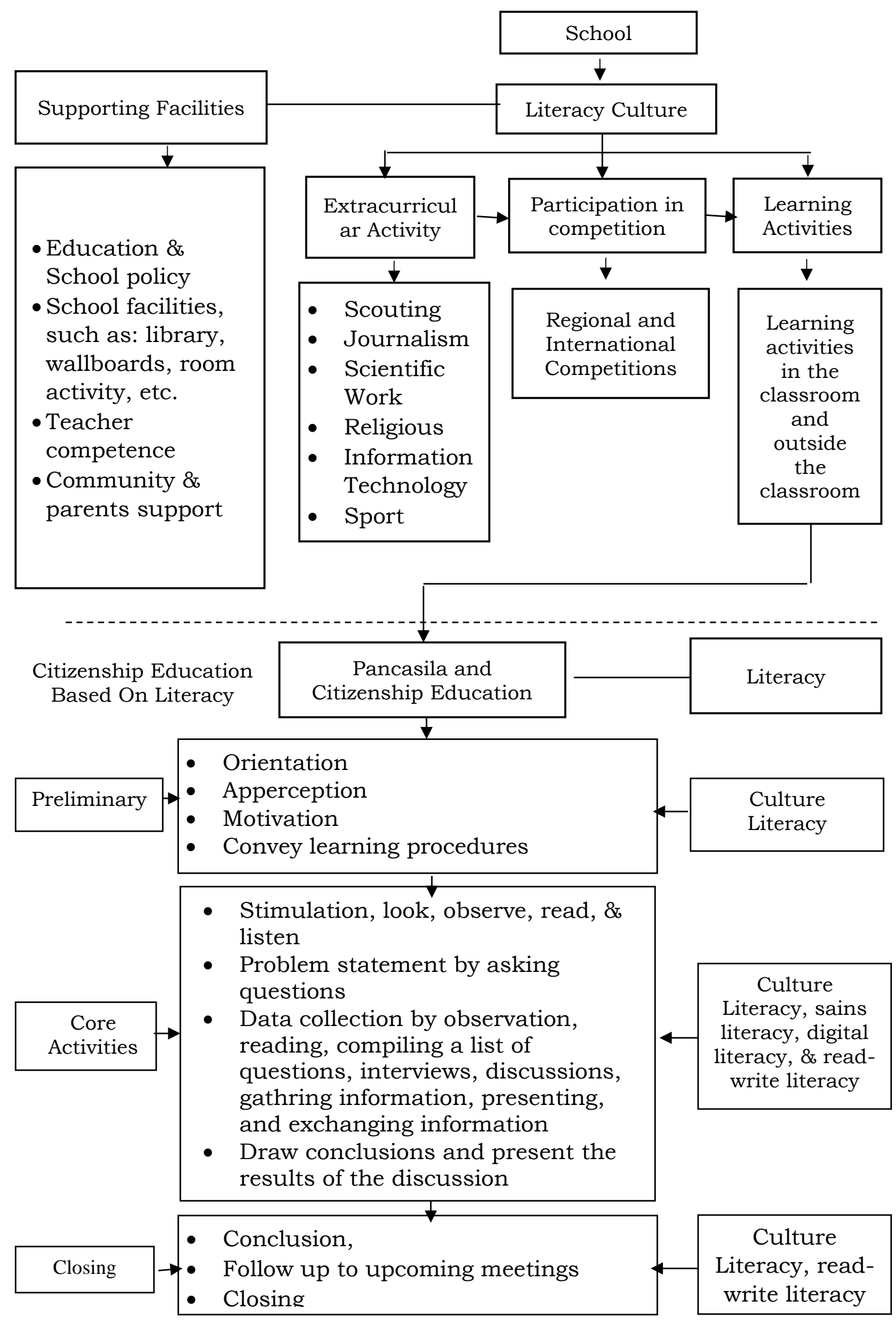

Figure 3. Pancasila and citizenship education learning model based on literacy at senior high school 


\section{CONCLUSION}

We can conclude that that the literacy based on Pancasila and citizenship education learning model in senior high schools were: first, school support about literacy culture. Literacy culture facilities include education and school policies and school facilities. Second, the development of literacy based on Pancasila and citizenship education learning include: (1) preliminary stages include: orientation, apperception, motivation, and giving ignorance. Literacy developed is cultural literacy. (2) The core stages include stimulation, problem statements, data collection, verification, and concluding. The literacy developed is cultural literacy, literacy, digital literacy, and scientific literacy. (3) The concluding stage includes summarizing conclusions, reinforcement, feedback, and closing greetings. Literacy activities developed are cultural literacy and reading-writing literacy.

\section{ACKNOWLEDGEMENT}

We thank the principal, teachers, and students of Senior High School 1 Sewon, Vocational High School 1, Health Vocational High School, and Muhammadiyah Senior High School, Bantul Regency of Yogyakarta, who have actively contributed to this research.

\section{REFERENCES}

Benaziria, B. (2018). Pengembangan literasi digital pada warga negara muda dalam pembelajaran PPKn melalui model VCT. Jupiis: Jurnal Pendidikan Ilmu-Ilmu Sosial, 1O(1), 11. doi: 10.24114/jupiis.v10i1.8331.

Bomer, R., Land, C. L., Rubin, J. C., \& Van Dike, L. M. (2019). Constructs of teaching writing in research about literacy teacher education. Journal of Literacy Research, 51(2), 196-213. doi: 10.1177/108629-6X19833783.

Bowo. A. N. A. (2015). Cerita Cinta Belajar Mengajar. Yogyakarta: Deepublish.

Bowo, A. N. A. (2016). Implementasi pembelajaran PKN berbasis inklusi di homeschooling. Academy of Education Jurnal, 7(2).

David L. Grossman, Wing On Lee, K. J. K. (2008). Citizenship Curriculum In Asia and The Pacific. Hong Kong: Comparative Education Research Centre Faculty of Education, The University of Hong Kong.

GLN (2017). Panduan Gerakan Literasi Nasional. Jakarta: Ministry of Education.

Grant, A. N. (1986). Defining literacy. Australian Review of Applied Linguistics, 9(2), 1-22. doi: 10.1075/aral.9.2.01gra.

Leksono, I. P. (2019). Bahan ajar PPKn berbasis karakter dan literasi untuk siswa Kelas IX SMP Al Hikmah Surabaya. Kajian Teknologi Pendidikan Jurnal, 4(2).

Lestari, R., Astuti, B., \& Bhakti, C. P. (2020). A comprehensive teacher strategy for successful online learning process. International Journal on Education Insight, 1(1), 1-12. doi: 10.12928/ijei.v1i1.2064.

Mangeya, H. (2019). Graffiti as a site for cultural literacies in Zimbabwean urban high schools. International Journal of Cultural Studies, 22(3), 334-348. doi: $10.1177 / 1367877918788577$.

Marmoah, S., \& Hartono, S. (2019). Implementation of school-based management through a culture of literacy in elementary schools. Riset Pedagogik Journal, 3(2).

Merga, M. K., Roni, S. M., \& Malpique, A. (2020). School leadership and wholeschool support of struggling literacy learners in secondary schools. Educational Management Administration and Leadership, 20(10), 1-17. doi: 
$10.1177 / 1741143220905036$.

Nuryadi, \& Tolib. (2017). Pendidikan Pancasila dan Kewarganegaraan. Retrieved from: https://doi.org/10.1046/j.-1523-1739.2003.00432.x.

Nuryati, Budiutomo, T., \& Bowo, A. N. A. (2017). Pengembangan model pembelajaran PPKn anti korupsi berbasis lingkungan melalui cooperative learning di SMA/SMK Swasta Kulon Progo Yogyakarta. Academy of Education Journal, 8(1).

Paristiyanti, N. (2016). Pendidikan Pancasila (I). Jakarta: Ristekdikti.

Pike, J. M. H. and M. A. (2006). Citizenship and Moral Education (1st ed.). Routledge Taylor \& Francis Group.

Rintaningrum, R. (2009). Literacy: Its importance and changes in the concept and definition. Teflin Journal, 20.

Saadati, B. A., \& Sadli, M. (2019). Analisis pengembangan budaya literasi dalam meningkatkan minat membaca siswa di sekolah dasar. TERAMPIL: Jurnal Pendidikan dan Pembelajaran Dasar, 6(2), 151-164. doi: 10.24042/terampil.v6i2.4829.

Widiatmaka, P. (2016). Kendala Pendidikan kewarganegaraan dalam membangun karakter peserta didik di dalam proses pembelajaran. Jurnal Civics, 13(2).

Winataputra, U. S. (2016). Posisi akademik Pendidikan Kewarganegaraan (PKn) dan muatan/mata pelajaran Pendidikan Pancasila dan Kewarganegaraan (PPKn) dalam konteks Sistem Pendidikan Nasional Jurnal Moral Kemasyarakatan, 1(1). doi: 10.21067/JMK.-V1I1.1184. 